\title{
Bruk av amniocenteser og chorionbiopsier i Norge
}

\author{
Guttorm Haugen ${ }^{1}$ og Carl Birger van der Hagen ${ }^{2}$ \\ ${ }^{1}$ Kvinneklinikken, Rikshospitalet, 0027 Oslo \\ ${ }_{2}^{2}$ Institutt for Medisinsk Genetikk, Universitetet i Oslo, 0315 Oslo \\ Korrespondanse til: Overlege dr.med. Guttorm Haugen, Kvinneklinikken, Rikshospitalet, 0027 Oslo \\ Telefon $22869200 \quad$ Telefax 22869235
}

\begin{abstract}
SAMMENDRAG
Invasiv prenatal diagnostikk i form av amniocentese (fostervannsprøve) og chorionbiopsi (morkakeprøve) utføres i ca. $2 \%$ av alle svangerskap i Norge per år. Dette er betydelig færre undersøkelser enn hva som utføres i de andre nordiske land. De fleste får utført amniocentese pga. høy maternell alder (aldersindikasjon) som her i landet er $\geq 38$ år ved fødselstermin. Chorionbiopsi er forbeholdt kvinner med kjente arvelige lidelser i familien, dvs. kvinner med høy risiko for å få et affisert foster. De undersøkelser som foreligger over svangerskapsutfall samt forekomst av komplikasjoner etter amniocentese og chorionbiopsi er hovedsakelig utført i andre land på kvinner med generelt lavere risiko ( $\geq 35$ år) enn for dem som får utført invasiv prenatal diagnostikk i Norge. Pga. vår restriktive praksis kan ikke disse resultatene uten videre overføres til Norge. Vi mangler eksakte data over svangerskapsutfall og evt. komplikasjoner etter disse undersøkelsene i en norsk populasjon.
\end{abstract}

\section{Haugen G, van der Hagen CB. The use of amniocentesis and chorionic villus sampling in Norway. Nor J Epidemiol 1997; 7 (1): 29-32.}

\section{ENGLISH SUMMARY}

Amniocentesis or chorionic villus sampling are performed in about $2 \%$ of all pregnancies in Norway which is far less than in the other Nordic countries. Most of the amniocenteses are performed due to advanced maternal age. In Norway this is defined as maternal age $\geq 38$ years at term. Couples with known chromosomal aberrations or genetic diseases in their families, i.e. women at a high risk of having an affected fetus, are offered chorionic villus sampling. Earlier studies on complications and pregnancy outcome following amniocentesis or chorionic villus sampling have been performed in other countries mainly on women at a lower risk ( $\geq 35$ years) than for the women having such tests in Norway. We do not have data on pregnancy outcome and possible complications following amniocentesis and chorionic villus sampling in a Norwegian population.

\section{INNLEDNING}

Den mest benyttede metoden for invasiv fosterdiagnostikk i Norge er amniocentese (fostervannsprøve). Undersøkelse av celler i fostervannet gir informasjon om kromosommønsteret til fosteret mens forhøyede verdier av alfa-føtoprotein $\mathrm{i}$ fostervannet er korrelert til nevralrørs- og bukveggsdefekter. Chorionbiopsi (morkakeprøve) har kommet som et viktig supplement de siste 10 årene.

I de nordiske land er det stor variasjon i bruken av invasiv prenatal diagnostikk (1). I 1990 fikk 11,9\% av alle gravide i Danmark utført amniocentese eller chorionbiopsi. De tilsvarende tall var for Finland
$7,2 \%$, for Sverige $4,7 \%$ og for Island $9,6 \%$. Av disse undersøkelsene ble $25 \%$ utført som chorionbiopsier i Danmark, 29\% i Finland, 17\% i Sverige og 0,4\% på Island. I Norge utføres betydelig færre amniocenteser og chorionbiopsier enn i de andre nordiske land. I 1990 fikk $2 \%$ av de gravide utført slike undersøkelser. Variasjonen mellom de nordiske land gjenspeiler først og fremst forskjellige aldersgrenser hvor man tilbyr amniocentese pga. maternell alder ("aldersindikasjon"). I sin behandling av Stortingsmelding nr. 25, 1992-93, "Om mennesker og bioteknologi", gikk et flertall i sosialkomiteen i Stortinget inn for at aldersgrensen skal være 38 år eller eldre ved fødselstermin. Situasjoner hvor det er aktuelt med genetisk foster- 
diagnostikk i Norge er beskrevet i et rundskriv fra Helsedirektøren av 30. desember 1983 med senere tilføyelser (Tabell 1). I følge Lov om medisinsk bruk av bioteknologi av 5. august 1994 kan invasiv prenatal diagnostikk bare finne sted ved godkjent institusjon.

\section{AMNIOCENTESE}

Det utføres ca. 1500 amniocenteser per år i Norge. De fleste får utført dette pga. "aldersindikasjon". Aldersgrensen på 38 år er valgt relativt vilkårlig pga. politiske hensyn (2). Ca halvparten av de aktuelle kvinnene tar imot dette tilbudet med store geografiske forskjeller. Amniocentese er den viktigste invasive metoden for å diagnostisere nevralrørsdefekter. Foreldre som tidligere har fått barn med kromosomavvik tilbys også amniocentese. For de andre situasjonene som er nevnt i tabell 1, har chrorionbiopsi i stor grad overtatt som den viktigste undersøkelsesmetoden. I tillegg tilbys amniocentese hvor det evt. påvises føtale avvik ved ultralyd. I 1995 ble 54 av 620 amniocenteser ved Kvinneklinikken, Rikshospitalet, utført pga. funn ved Ultralydlaboratoriet.

Selve prøvetakingen foregår ved kvinneklinikkene ved regionsykehusene. Prøvene analyseres ved avdelingene for medisinsk genetikk ved Ullevål sykehus, Haukeland sykehus og ved Regionsykehuset i Tromsø.

Amniocentese har tradisjonelt blitt utført i 16. til 18. svangerskapsuke. De senere årene er det blitt vanlig å ta prøven tidligere, såkalt tidlig amniocentese, oftest definert som amniocentese før uke 15. I Norge har vi ikke noe standardisert tidspunkt for prøvetakingen, men den vil vanligvis vil bli utført i løpet av de nærmeste ukene fra uke 13 eller 14. Resultatet av alfa-føtoprotein konsentrasjonen vil foreligge innen dager, og svar på kromosommønsteret vil vanligvis foreligge innen tre uker.

En prospektiv randomisert studie av amniocenteser tatt ved tradisjonelt tidspunkt har vist ca. $1 \%$ risiko for spontan abort relatert til prøvetakingen (3). Foreløpig finnes ingen tilsvarende kontrollert studie for tidlig amniocentese. En kanadisk prospektiv pilotundersøkelse, hvor tidlig amniocentese ble sammenlignet med amniocentese på konvensjonelt tidspunkt, har ikke vist noen øket forekomst av aborter (4). Enkelte retrospektive studier har derimot vist en mulig forøket risiko for spontan abort etter tidlig amniocentese $(5,6)$. Det foreligger også data som viser øket frekvens av feilslåtte kulturer jo tidligere prøven er utført (6). Nicolaides et al. viste $\mathrm{i}$ sin studie over tidlig amniocentese en frekvens av feilslåtte kulturer på 5,3\% i uke 10, 2,1\% i uke $11,1,2 \%$ i uke 12, men ingen feilslåtte kulturer i uke 13 (7). Av mindre komplikasjoner relatert til punksjonen forekommer fostervannslekkasje og abdominalsmerter hos mor. Neonatalt har enkelte studier påvist øket morbiditet, mens dette ikke er verifisert $\mathrm{i}$ andre undersøkelser. I en nylig publisert kanadisk registerstudie hvor barna ble fulgt opp til 7-18 års alder, var det eneste signifikante funn en overhyppighet av ABO uforlikelighet neonatalt etter svangerskap hvor det var utført amniocentese (8). De overnevnte studiene omfatter hovedsakelig kvinner som fikk utført amniocentese på "aldersindikasjon" som i de aktuelle landene er 35 år eller eldre. I Norge utføres imidlertid amniocentesene hovedsakelig på en populasjon med generelt høyere risiko for komplikasjoner ( $\geq 38$ år). Pga. det lave antall undersøkelser får vi et mindre erfaringsgrunnlag og resultatene fra studier $i$ andre land kan ikke uten videre overføres til norske forhold.

\section{CHORIONBIOPSIER}

Chorionbiopsier er først og fremst utviklet som en prosedyre i første trimester for å få en diagnose på fosteret tidlig i svangerskapet. Teknikken for chorionbiopsi er utviklet fra slutten av 1960-årene, men først i løpet av 1980-årene ble chorionbiopsi utviklet til hva det er i dag med ultralydledet teknikk. Prøven kan taes via livmorhalsen ved innføring av et bøyelig plastkateter eller transabdominalt ved bruk av punksjonsnål inn i placenta. Chorion villi aspireres i en sprøyte med kulturmedium. Hvilke metode som benyttes primært er i stor grad avhengig av erfaring. Fra WHO er det imidlertid anbefalt at begge metoder er tilgjengelig da valg av teknikk bl.a. vil være avhengig av placentas lokalisasjon (9).

Tabell 1. Aktuelle problemsituasjoner hvor genetisk fosterdiagnostikk er aktuelt. (Fra Helsedirektørens rundskriv om genetisk fosterdiagnostikk av 30. desember 1983 med senere tilføyelser.)

1. Foreldre som har øket risiko for å få barn med en kromosomsykdom på grunn av kvinnens alder.

2. Foreldre som tidligere har fått barn med kromosomsykdom.

3. Foreldre som tidligere har fătt et barn med nevralrørsdefekt.

4. Pasienter som bruker antiepileptika.

5. Foreldre som tidligere har fått et barn med medfødt stoffskiftesykdom hvor det er mulig å utføre fosterdiagnostikk.

6. Foreldre som tidligere har fått et barn med alvorlig X-bundet recessiv sykdom eller hvor det er høy risiko for at kvinnen er bærer av slikt sykdomsanlegg.

7. Hvor en av foreldrene er bærer av en kromosomanomali og dermed har høy risiko for å få barn med alvorlig utviklingsforstyrrelse. 
I mange andre land tilbys chorionbiopsi til kvinner med relativ lav risiko for kromosomavvik, f.eks. alder $\geq 35$ år. I Norge utføres ca. 45 chorionbiopsier per år. Det er først og fremst kvinner med høy risiko for å få et affisert foster som får dette tilbudet. Dette gjelder 1) foreldre som tidligere har fått et alvorlig affisert barn hvor det foreligger tilgjengelig fosterdiagnostikk med DNA- eller biokjemiske teknikker, 2) foreldre med tidligere barn med X-bundet recessiv sykdom eller hvor det er høy risiko for at kvinnen er bærer av slikt sykdomsanlegg, 3) hvor en av foreldrene er translokasjonsbærer. Enkelte har også fått utført chorionbiopsi pga. høy maternell alder (> 40 år) og tidligere tung sykehistorie. Den siste situasjonen gjelder f.eks. kvinner som tidligere har fått barn med kromosomavvik eller som har gjennomgått en senabort pga. fostermisdannelser.

I Norge ble de første chorionbiopsiene utført ved årsskiftet 1986-87 (overlege Sverre Stray-Pedersen, Kvinneklinikken, Rikshospitalet). Til nå er det utført ca. 350 biopsier i Norge. Prøvene analyseres ved avdelingene for medisinsk genetikk ved Ullevål sykehus og Haukeland sykehus. Enkelte prøver sendes også til laboratorier i utlandet for nærmere DNA- eller biokjemisk analyse.

Fra desember 1986 til desember 1995 ble det ved Kvinneklinikken, Rikshospitalet, utført chorionbiopsi i 216 svangerskap. Indikasjonen for chorionbiopsi i disse svangerskapene var: Translokasjonsbærere $(\mathrm{n}=34)$, X-bundet sykdom $(\mathrm{n}=88)$, stoffskiftesykdom $(\mathrm{n}=66)$ og maternell alder, tidligere foster med kromosomavvik eller annen tung sykehistorie $(\mathrm{n}=28)$. I disse svangerskapene var 56 av fostrene affisert. Dette høye antallet er å forvente ut fra de aktuelle indikasjonene.

Prospektivt randomiserte undersøkelser har vist varierende risiko for spontane aborter relatert til prøvetakingen. Det er påvist høyere (10), uendret (11) samt lavere (7) frekvens sammenlignet med risikoen etter amniocentese. En dansk undersøkelse viste at risikoen for spontan abort var relatert til teknikken ved prøve- taking (12). To andre prospektive randomiserte undersøkelser har ikke kunnet verifisere dette $(13,14)$.

Fra 1991 kom enkelte rapporter som viste en øket frekvens av amputasjonsskader på armer og ben hos fosteret etter chorionbiopsier (15). Det ble antydet en sammenheng mellom tidspunkt for prøvetaking og risikoen for slike skader. Imidlertid er det i en nylig publisert registerstudie som ble initiert av WHO ikke vist noen overhyppighet av amputasjonsskader hos fosteret (16). Undersøkelsen viste 77 tilfeller av aktuelle defekter på armer og ben etter ca. 139000 biopsier. Dette representerer ingen økning i forhold til normalbefolkningen. Det ble likevel anbefalt at prøven ikke utføres før uke 9. I Norge er det vanlig å utføre prøven mellom uke $91 / 2$ og 12, men prøven kan også utføres senere.

De cytogenetiske resultatene kan være vanskeligere å tolke ved chorionbiopsier enn ved amniocentese. Blant annet forekommer kromosommosaikk noe hyppigere ved chorionbiopsi (ca. 1\%) $(8,9)$. Dette representerer ikke nødvendigvis kromosommønsteret hos fosteret, og det endelige svaret må avklares gjennom fornyet undersøkelse med amniocentese. Dette stiller store krav til veiledningen av pasientene. Generelt er det antatt at chorionbiopsi krever større ressurser sammenlignet med amniocentese både for genetiker og gynekolog.

\section{KONKLUSJON}

Aldersgrensen hvor man tilbyr invasiv prenatal diagnostikk pga. maternell alder er høyere i Norge enn i land som det er vanlig å sammenligne seg med. I Norge utføres færre prøver på en populasjon med høyere risiko for svangerskapskomplikasjoner. Pga. vår restriktive praksis foreligger det et klart behov for å kartlegge komplikasjonsratene som kvinnen må regne med ved amniocentese eller chorionbiopsi utført i Norge. Dette vil gi kvinnen mer realistisk informasjon når hun skal ta stilling til evt. invasiv prenatal diagnostikk i svangerskapet.

\section{REFERANSER}

1. Brøndum-Nielsen K, Nørgaard-Pedersen B. Prenatal diagnostik i Norden. Nord Med 1993; 108: 189-192.

2. Norges Offentlige Utredninger 1991, 6. Mennesker og bioteknologi.

3. Tabor A, Madsen M, Obel EB, Philip J, Bang J, Nørgaard-Pedersen B. Randomised controlled trial of genetic amniocentesis in 4606 low-risk women. Lancet 1986; i: 1287-1293.

4. Johnson J-AM, Wilson RD, Winsor EJT, Singer J, Dansereau J, Kalousek DK. The early amniocentesis study: A randomized clinical trial of early amniocentesis versus midtrimester amniocentesis. Fetal Diagn Ther 1996; 11: 85-93.

5. Brumfield CG, Lin S, Conner W, Cosper P, Davis RO, Owen J. Pregnancy outcome following genetic amniocentesis at 11-14 versus 16-19 weeks' gestation. Obstet Gynecol 1996; 88: 114-118.

6. Sundberg K, Jørgensen FS, Tabor A, Bang J. Experience with early amniocentesis. J Perinat Med 1995; 23: 149-158. 
7. Nicolaides K, Brizot MDL, Patel F, Snijders R. Comparison of chorionic villus sampling and amniocentesis for fetal karyotyping at 10-13 weeks' gestation. Lancet 1994; 344; 435-439.

8. Baird PA, Yee IML, Sadovnick AD. Population-based study of long-term outcomes after amniocentesis. Lancet 1994; 344: 1134-1136.

9. Kuliev AM, Modell B, Jackson L, et al. Risk evaluation of CVS. Prenat Diagn 1993; 13: 197-209.

10. MRC Working Party on the Evaluation of Chorion Villus Sampling. MRC European trial of chorion villus sampling. Lancet 1991; 337: 1491-1499.

11. Canadian Collaborative CVS-Amniocentesis Clinical Trial Group. Multicentre randomised clinical trial of chorion villus sampling and amniocentesis. Lancet 1989; i: 1-6.

12. Smidt-Jensen S, Permin M, Philip J, Lundsteen C, Zachary JM, Fowler SE, Grüning K. Randomised comparison of amniocentesis and transabdominal and transcervical chorionic villus sampling. Lancet 1992; 340: 1237-1244.

13. Brambati B, Terzian E, Tognoni G. Randomized clinical trial of transabdominal versus transcervical chorionic villus sampling methods. Prenat Diagn 1991; 11: 285-293.

14. Jackson LG, Zachary JM, Fowler SE, et al. A randomized comparison of transcervical and transabdominal chorionic-villus sampling. N Engl J Med 1992; 327: 594-598.

15. Firth HV, Boyd PA, Chamberlain PF, MacKenzie IZ, Morriss-Kay GM, Huson SM. Analysis of limb reduction defects in babies exposed to chorionic villus sampling. Lancet 1994; 343: 1069-1071.

16. Froster UG, Jackson L. Limb defects and chorionic villus sampling: results from an international registry, 1992-1994. Lancet 1996; 347: 489-494. 